\title{
Relationships between Ownership Structures and Corporate Performance: Evidence from Malaysia
}

\author{
Sami R.M. Musallam (Dr.) \\ Senior Lecturer, Faculty of Business and Management, Asian Institute of Medicine, \\ Science, and Technology (AIMST) University, Malaysia \\ Email:samimslam@yahoo.com
}

\section{Doi:10.5901/mjss.2015.v6n3s1p70}

\begin{abstract}
This study aims to examine the impacts of ownership structures (foreign ownership, linearity of foreign ownership, state ownership, and linearity of state ownership on corporate performance using a panel data from Malaysia listed companies over a period of 2000 to 2009. Weighted Least Square (WLS) models are used to test the relationships. The results show that the impact of foreign ownership is positive and significant on corporate performance while the impact of state ownership is negative and significant on corporate performance. These results suggest that foreign ownership enhance corporate performance while state destroys corporate performance. Furthermore, the results also show that foreign and state ownerships have linear relationship with corporate performance. This study concludes that an increase in foreign ownership states may enhance corporate performance as linear relationship exists. Finally, this study provides evidence that investors may make appropriate investment decisions to invest in the companies linked with foreign ownership.
\end{abstract}

Keywords: Foreign Ownership, State Ownership, Control Variables, Corporate Performance, Malaysia

\section{Introduction}

Relationship of ownership structures and corporate performance is discussed widely in corporate governance literatures. Jensen and Meckling (1976) state that a high percentage owned by shareholders has a strong monitoring role to monitor managers, therefore reduce agency costs which helps firms to maximize their value. On the other hand, Berle and Means (1932) argue that managers with lower percentage of ownership may deploy their control for benefit themselves rather than maximizing shareholders value. Morck, Shleifer, and Vishny (1988) use a cross-section of 371 Fortune 500 companies in 1980 to re-examine the relation between ownership structure and performance. They use Market to Book Value Ratio (MTBVR) as a performance measure and board ownership as a minimum stake of $20 \%$ owned by shareholdings of all board members. They show no significant relation in the linear regressions using either MTBVR or accounting profit rate as performance measures. However, Benson and Davidson (2009) and Coles, Lemmon and Felix Meschke (2012) find that inside ownership has a significant linear relationship with corporate performance in their recent studies.

There is an increased recognition on the importance of foreign ownership in emerging markets. Khanna and Palepu (2000) argue that foreign ownership performs an effective monitoring function of the firm management. Foreign ownership often contributes to managerial and organizational capabilities by providing organizational resources and knowledge in addition to financial capital. Hence, Chibber and Majumdar (1999) argue that foreign ownership may impose more resources to knowledge transfer. Foreign ownership tends to impose a good corporate governance practices in companies that invest in them. Bekaert and Harvey (2000) report that several countries have increasingly opened their markets for attractive foreigners vary across countries with different legal system and corporate governance mechanism. For example in Malaysia, it has implemented important measure to attract and increase foreign investors to hold majority stakes in most listed companies as mentioned in the New Economic Model (NEM) in 2010.

To effectively implement NEM policy to increase foreign investors stake in Malaysian market, good understanding of the relationship between ownership and corporate performance is needed. One of the important issues in the relationship is linearity. The relationship could be linear and nonlinear. If the linear relationship exists, the performance improved and the policy is effective to implement. Otherwise the policy will be not supported. Most of Malaysian previous studies focus on foreign ownership only (see for example, Lau \& Tong, 2008; Sulong \& Mat Nor, 2010; Najid \& Abdul Rahman, 2011). Therefore, this study will look at foreign ownership and the linearity impact of foreign ownership on corporate performance. 
With respect of state ownership, previous studies argue that high state ownership has strong government protections and governance mechanisms and incentive to perform better (Le \& Buck, 2009). In addition, state ownership can monitor managers and positively influence corporate performance (Jiang, 2004). In contrast, Estrin and Perotin (1991) state that companies with government ownership share do not focus on profit maximization because state has economic objectives and different political, and that lead to inferior corporate performance in that companies because of weaker corporate governance arrangements. State ownership is different than government ownership and this type of ownership can be clearly distinguished from government ownership in Malaysia although it is impossible to differentiate these two ownerships in China (Le \& Buck, 2009). The study on state ownership and performance is limited in the Malaysian perceptive. Therefore, this study also looks at state ownership and the linearity effect of state ownership on corporate performance.

\section{Literature Reviews and Hypotheses}

Thomsen and Pedersen (2000) argue that foreign ownership has experience in dealing with managerial opportunism and mitigating agency conflicts in different national and cultural settings. Douma, George and Kabir (2006) examine the impact of foreign ownership on corporate performance in India. They point out that foreign ownership has a positive impact on corporate performance because foreigners have sufficient corporate governance in the internal system of the companies. Ongore (2011) conducts a study in Kenya to test the impact of several ownership categories on corporate performance. He finds that foreign ownership has positive and significant relationship with corporate performance. Furthermore, he argues that foreign investors can help to enhance management system and easy access to massive resources. Phung and Le (2013) examine the effect of foreign ownership on corporate performance for a sample of all Vietnamese listed companies from 2008 to 2011. They show that foreign ownership is negatively related to corporate performance because it is not enough concentrated. Therefore, it is hypothesis that:

H1a: foreign ownership has positive relationship with corporate performance

Chhibber and Majumdar (1999) and Taylor (1990) argue that foreign ownership can easy access to superior technical, managerial talents, and financial resources. Kim (2013) and Stulz (1999) argue that foreign ownership has strong monitoring of managers and reduced agency costs, thus leads to better performance. Furthermore, Kim (2013) states that managers in companies with large foreign ownership have sufficient control role because they focus well on long-term value. Thus, it can argue that when foreign ownership has more concentrated, foreign investors play a significant monitoring role in companies. Furthermore, when it has more concentrated, foreign ownership may enhance corporate performance because foreigners can transfer their resources such as financial and technological resources to the companies (Huang \& Shiu 2009; Gurbuz \& Aybars 2010). Therefore, it is also hypothesis that:

\section{$H_{1 b}$ : foreign ownership has inverted U-shaped relationship with corporate performance}

Wang (2005) conducts his study in China using a panel data of all initial public firm-year observations listed on Shenzhen Stock Exchange (SZSE) and Shanghai Stock Exchange (SHSE) during a period of 1994 to 1999 to test the impact of state ownership on corporate performance. He finds that state equity ownership has positive impact on corporate performance, meaning that state can monitor managers and lead to better performance. In contrast, Pervan, Pervan and Todoric (2012) study the influence of state ownership on corporate performance for a sample of all Croatian listed firms. They show that state ownership is negatively related to corporate performance. This finding is in line with Sun and Tong (2003), Qi, Wu, and Zhang (2000) in China, Ongore (2011) in Kenya, and Andres (2008) in German. On the other hand, Hess, Gunasekarage, and Hovey (2010) use 97 randomly selected Chinese sample during the period of 1997 to 1999. They show that state ownership is not associated with corporate performance. Therefore, it is also hypothesis that:

\section{$H_{2 a}$ : state ownership has negative relationship with corporate performance}

Sun, Tong, and Tong (2002) examine the linearity effect of state ownership for a sample of listed firms in China during a period from 1994 to 1997. They find that state ownership has an inverted U-shaped with corporate performance, meaning that a high state ownership initially increases performance, but performance after certain level decreases. However, Yu (2013) investigate the relationship between the linearity of state ownership and corporate performance using a panel data of Chinese listed firms from 2003 and 2010. He finds that state ownership has U-shaped relationship 
with corporate performance. Suggesting that as the size of shareholders by state increases, firm performance initially decreases and then increases. Further, Hess et al. (2010) use a balanced sample of 5170 firm-years of Chinese listed firms during a period of 2000 to 2004 and they reconfirm that state ownership has U-shaped relationship with corporate performance. Therefore, it is also hypothesis that:

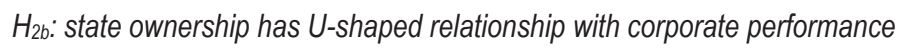

\section{Methodology}

This study uses a sample of 190 non-financial companies listed on Bursa Malaysia over the period of 2000 to 2009. Data was collected for these companies in respect of the period 2000 to 2009 or up to the year before delisting. This procedure leads to the final sample of 1716 company-year observations. MTBVR is used as the dependent variable to measure corporate performance. Further, ROA is a common accounting measure of corporate performance also used for robustness check because MTBVR in emerging markets with weak shareholder protection can be biased (Claessens \& Djankov 1999). The data on ownership is hand collected from annual reports while the rest of the data is collected from DataStream. Table 1 presents measurements of the variables used in the study.

Table 1. Measurements of variables

\begin{tabular}{|c|c|}
\hline Variables & Descriptions \\
\hline \multicolumn{2}{|l|}{ Dependent variables } \\
\hline MTBV $_{\text {it }}$ & $\begin{array}{l}\text { Market to book value of company } \mathrm{i} \text { in year t. MTBVR is measured by market price-year end / } \\
\text { book value per share }\end{array}$ \\
\hline ROA & $\begin{array}{l}\text { Return on assets of a company } \mathrm{i} \text { in year t. ROA is measured by [(net income before preferred } \\
\text { dividends }+ \text { (interest expense on debt-interest capitalized }) *(1 \text {-tax rate) }] \text { / average of last year's } \\
\text { and current year's total assets * } 100 \text {. }\end{array}$ \\
\hline \multicolumn{2}{|r|}{ 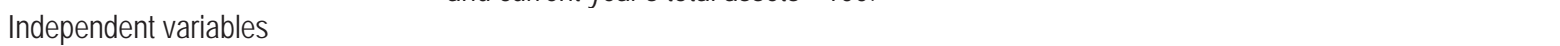 } \\
\hline Foreign ownership (Ownership it) & Foreign ownership in company i in year t. \\
\hline State Ownership (Ownership it) & State ownership in company $\mathrm{i}$ in year $\mathrm{t}$. \\
\hline Firm Size (LN (FSIZE) $)_{i t}$ & The natural logarithm of total assets of company $\mathrm{i}$ in year $\mathrm{t}$. \\
\hline Firm Age (LN (FAGE)it) & The natural logarithm of firm age since listed on BM of company $\mathrm{i}$ in year $\mathrm{t}$. \\
\hline Leverage Ratio (LEV ${ }_{\text {it }}$ ) & Long term debt divided by total assets of company $\mathrm{i}$ in year t. \\
\hline Profitability (PROF it) & Operating earnings divided by total sales of company i in year t. \\
\hline Investment (INV it) & Capital expenditure divided by total sales of company i in year t. \\
\hline Capital intensity (CAPIN $\left.N_{i t}\right)$ & Tangible assets divided by total assets of company $\mathrm{i}$ in year $\mathrm{t}$. \\
\hline Liquidity (LIQUIDit) & Cash and cash equivalent divided by total assets of company $\mathrm{i}$ in year $\mathrm{t}$. \\
\hline
\end{tabular}

To identify the specific effect of ownership on corporate performance, this study uses firm age, firm size, leverage ratio, profitability, capital intensity, investment, and liquidity as control variables that might affect performance. However, the effects of these seven variables are not clear (see Amran and Ahmad (2010) and Oxelheim and Randoy (2003) for firm size, firm age, and leverage; Claessens, Djankov, \& Lang (2000) for profitability; Konijn, Kräussl, and Lucas (2011) for investment and Capital intensity; Thomsen and Pedersen (2000) for liquidity). This study uses Panel data to analyze the affect of independent variables on performance. A panel data analysis is used because it can eliminate the unobservable heterogeneity that exists in the sample (Himmelberg, Hubbard, \&Palia, 1999). Panel data is also used because it gives researchers a large number of data points, increases the degree of freedom, and decreasing the collinearity effects. It also improves the effectiveness of statistical estimates (Hsiao, 2003). The following models are estimated: Corporate performance it $=B_{0}+B_{1}$ Ownership $_{i t}+B_{2} L N(F S I Z E)_{i t}+B_{3} L N(F A G E)_{i t}+B_{4} L E V_{i t}+B_{5}$ PROF $_{i t}+B_{6} I N V_{i t}+$ $B 7{ }_{7}$ CAPIN ${ }_{i t}+B_{8} L_{I Q U I D}+e_{i t}$ Corporate performance $_{i t}=B_{0}+B_{1}$ Ownership $_{i t}+B_{2}$ Ownership $_{i t}+B_{3} L N(F S I Z E)_{i t}+B_{4} L N(F A G E)_{i t}+B_{5} L E V_{i t}+B_{6}$ $\mathrm{PROF}_{\mathrm{it}}+\mathrm{B}_{7} \mathrm{NVV}_{\mathrm{it}}+\mathrm{B}_{8} \mathrm{CAPIN} \mathrm{Hit}^{+} \mathrm{Bg}_{9} \mathrm{LIQUID}_{\mathrm{it}}+\mathrm{e}_{\mathrm{it}}$ Where the variables are described in Table 1

\section{Results and Discussion}

Table 2 shows descriptive statistics of the variables used in the study. The mean values for MTBVR and ROA during 2000 to 2009 are 1.177 and 0.031 respectively, which indicate that within this period the market appreciate listed 
companies in average. However, the range of MTBVR and ROA are from lowest value of -240.380 and -1.058 to highest value of 36.170 and 6.786 respectively. The table also shows that while foreign ownership accounts for a higher percentage in ownership structures of listed companies with a mean of 4.240 , the mean value of state ownership only 0.012. This indicates that in average foreign ownership is concentrated, but not state ownership.

Table 2. Descriptive statistics of the variables

\begin{tabular}{ccccc}
\hline Variables & Minimum & Maximum & Mean & Std. Deviation \\
\hline MTBVR & -240.380 & 36.170 & 1.177 & 6.350 \\
ROA & -1.058 & 6.786 & 0.031 & 0.209 \\
FO & 0.000 & 57.510 & 4.240 & 7.008 \\
STATE & 0.000 & 0.62 & 0.012 & 0.066 \\
FAGE & 0.000 & 3.610 & 2.430 & 0.533 \\
FSIZE & 7.474 & 18.451 & 12.879 & 1.404 \\
LEV & 0.000 & 24.099 & 0.113 & 0.598 \\
PROF & -164.397 & 151.468 & 0.113 & 5.952 \\
INV & 0.000 & 0.013 & 0.001 & 0.001 \\
CAPIN & -86.462 & 17.734 & 0.419 & 3.592 \\
LIQUID & 0.000 & 3.365 & 0.051 & 0.158
\end{tabular}

Notes. Total number of observations for all variables are 1716, For the definition of variables refer to the table 1.

Pearson's correlation is used to measure the degree of relationship between the independent variables in this study. Table 3 presents the correlation results. Based on the results, none of the correlation coefficients has a value higher than 0.8 or 0.9 , which show that there is no problem of multicollinearity (Judge, Hill, Griffiths, Lutkepohl, \& Lee, 1988).

Table 3. Correlation matrix between variables

\begin{tabular}{|c|c|c|c|c|c|c|c|c|c|c|c|}
\hline Variables & MTBVR & $\mathrm{ROA}$ & STATE & FO & FAGE & FSIZE & LEV & PROF & INV & CAPIN & LIQUID \\
\hline $\begin{array}{l}\text { MTBVR } \\
\end{array}$ & 1 & & & & & & & & & & \\
\hline ROA & $\left.0.1066^{(*}\right)$ & 1 & & & & & & & & & \\
\hline STATE & -0.013 & -0.014 & 1 & & & & & & & & \\
\hline FO & 0.003 & 0.024 & $-0.056\left(^{*}\right)$ & 1 & & & & & & & \\
\hline FAGE & 0.023 & 0.029 & -0.028 & $0.107(* *)$ & 1 & & & & & & \\
\hline FSIZE & 0.016 & 0.027 & 0.033 & $0.215^{\left({ }^{*}\right)}$ & $0.332^{\left({ }^{*}\right)}$ & 1 & & & & & \\
\hline LEV & -0.004 & -0.008 & -0.009 & 0.004 & -0.011 & 0.008 & 1 & & & & \\
\hline PROF & 0.012 & $0.088^{\left({ }^{\star}\right)}$ & 0.000 & 0.027 & -0.012 & $\left.0.101{ }^{(* *}\right)$ & 0.001 & 1 & & & \\
\hline INV & 0.017 & 0.033 & -0.017 & 0.007 & $-0.068(* *)$ & $\left.-0.050^{*}\right)$ & 0.000 & $0.4511^{(* *)}$ & 1 & & \\
\hline CAPIN & $\left.-.0050^{*}\right)$ & $-0.418{ }^{(* *)}$ & 0.007 & 0.012 & 0.023 & $\left.0.0977^{(* *}\right)$ & $-0.480^{(* *)}$ & 0.015 & 0.006 & 1 & \\
\hline LIQUID & 0.011 & -0.011 & -0.001 & -0.045 & 0.022 & $-0.186^{(* *)}$ & -0.033 & 0.007 & 0.024 & 0.015 & 1 \\
\hline
\end{tabular}

Note. * Correlation is significant at the 0.05 level; ${ }^{*}$ Correlation is significant at the 0.01 level; For the definition of variables refer to the table 1.

Table 4 shows the empirical results of OLS and WLS estimations. Results of OLS are summarized in column 2 and column 4 of Table 4. It shows that OLS method suffers from heteroscedasticity problem based on Cook-Weisberg (CW) or Breusch-Pagan (BP) test that gives value 107.43 and 107.43 respectively with $p$-value of 0.000 . Since OLS estimation suffers from heteroscedasticity problem, WLS is used.

The results of model (1) using WLS presented in column 3 and column 6 of Table 4. The result shows that foreign ownership is positively and significantly related to corporate performance. This finding is consistent with hypothesis (1a). It indicates that foreign investors may monitor the management of companies more closely and hence improve the company performance. As they hold a larger stake in a company, their wealth is more tied to the performance of the company. Thus, they have more incentive to monitor managerial behaviors and ascertain that managerial actions are congruent with wealth maximization. The results also show that the effect of firm age is negative on corporate performance while the effects of firm size, the profitability, and liquidity are positive on corporate performance.

The result of the impact of state ownership on corporate performance has the result of coefficient consistent with the hypothesis (2a) which means that higher ownership by the state government does not lead to better monitoring. This result is consistent with findings by Pervan et al. (2012) Sun and Tong (2003) and Wei and Varela (2003). The results of 
model (2) using WLS are also presented in column 4 and column 7 of Table 4. It shows that foreign or state ownership have linear relationship with corporate performance. These findings are not in line with hypothesis (1b) and hypothesis (2b).

Table 4. Model (1) Regression results of OLS and WLS methods

\begin{tabular}{ccccccc}
\hline \multirow{2}{*}{ Variables } & \multicolumn{3}{c}{$\begin{array}{c}\text { Regression result of foreign ownership on } \\
\text { company performance }\end{array}$} & \multicolumn{3}{c}{ Regression result of state ownership on company } \\
performance
\end{tabular}

Note. * Correlation is significant at the 0.05 level; ${ }^{*}$ Correlation is significant at the 0.01 level; For the definition of variables refer to the table 1.

\section{Robust Analyses}

In order to provide a robustness of the results, this study uses ROA as an alternative measure of corporate performance. The result of model (1) and model (2) using ROA as dependent variable is summarized in table 5 . The results show that the model using ROA as company performance variable has consistent with hypothesis (1a) and hypothesis (2a). Furthermore, the results also show that the model using ROA as corporate performance variable has not consistent with hypothesis (1b) and hypothesis (2b). This implies that foerign or state ownerships have linear relationship with market and accounting performance measures.

Table 5. Model (1) and (2) Regression results of WLS method using ROA as corporate performance

\begin{tabular}{lcccc}
\hline Variables & $\begin{array}{c}\text { Regression result of foreign ownership on company } \\
\text { performance }\end{array}$ & $\begin{array}{c}\text { Regression result of state ownership on company } \\
\text { performance }\end{array}$ \\
\hline Const & -0.09 & -0.059 & -0.094 & -0.095 \\
& $(0.000)^{\star \star \star}$ & $(0.000)^{\star \star \star}$ & $(0.000)^{\star \star \star}$ & $(0.025)$ \\
Ownership & 0.036 & 0.048 & -0.060 & -0.381 \\
Ownership2 & $(0.059)^{\star}$ & $(0.107)$ & $(0.005)^{\star \star *}$ & $(0.115)$ \\
\hline
\end{tabular}




\begin{tabular}{|c|c|c|c|c|}
\hline & & $(0.593)$ & & $(0.166)$ \\
\hline FAGE & 0.007 & 0.007 & 0.007 & 0.006 \\
\hline & $(0.013)^{\star \star}$ & $(0.000)^{\star \star \star}$ & $(0.007)^{\star \star \star}$ & $(0.477)$ \\
\hline FSIZE & $\begin{array}{c}0.008 \\
(0.000)^{\star \star \star}\end{array}$ & $\begin{array}{c}0.005 \\
(0.000)^{\star * *}\end{array}$ & $\begin{array}{c}0.008 \\
(0.000)^{\star \star \star}\end{array}$ & $\begin{array}{c}0.011 \\
(0.002)^{\star \star \star}\end{array}$ \\
\hline LEV & $\begin{array}{c}-0.028 \\
(0.000)^{\star \star \star}\end{array}$ & $\begin{array}{c}-0.036 \\
(0.000)^{\star \star \star}\end{array}$ & $\begin{array}{c}-0.031 \\
(0.000)^{\star \star \star}\end{array}$ & $\begin{array}{c}-0.096 \\
(0.000)^{\star \star \star}\end{array}$ \\
\hline PROF & $\begin{array}{c}0.003 \\
(0.000)^{\star \star \star}\end{array}$ & $\begin{array}{c}0.002 \\
(0.000)^{\star \star \star}\end{array}$ & $\begin{array}{c}0.003 \\
(0.000)^{\star \star \star}\end{array}$ & $\begin{array}{c}0.003 \\
(0.000)^{\star \star \star}\end{array}$ \\
\hline INV & $\begin{array}{l}-13.068 \\
(0.042)^{\star \star}\end{array}$ & $\begin{array}{c}-9.161 \\
(0.071)^{\star}\end{array}$ & $\begin{array}{c}-13.313 \\
(0.033)^{\star \star}\end{array}$ & $\begin{array}{c}0.425 \\
(0.968)\end{array}$ \\
\hline CAPIN & $\begin{array}{c}0.001 \\
(0.401)\end{array}$ & $\begin{array}{c}0.009 \\
(0.073)^{\star}\end{array}$ & $\begin{array}{c}0.001 \\
(0.476)\end{array}$ & $\begin{array}{c}-0.032 \\
(0.000)^{\star \star \star}\end{array}$ \\
\hline LIQUID & $\begin{array}{c}0.007 \\
(0.355)\end{array}$ & $\begin{array}{c}0.005 \\
(0.623)\end{array}$ & $\begin{array}{c}0.008 \\
(0.310)\end{array}$ & $\begin{array}{c}0.003 \\
(0.892)\end{array}$ \\
\hline $\mathrm{R}^{2}$ & 0.079 & 0.086 & 0.082 & 0.247 \\
\hline Adjusted R2 & 0.075 & 0.081 & 0.078 & 0.243 \\
\hline F-statistic & 18.518 & 17.852 & 19.267 & 62.197 \\
\hline P-value(F) & 0.000 & 0.000 & 0.000 & 0.000 \\
\hline
\end{tabular}

\section{Conclusion}

This study examine the relationship between foreign ownership, linearity of foreign ownership, state ownership, and linearity of state ownership using a panel data of 190 Malaysian listed companies during a period of 2000 to 2009 . WLS model is used in this study to estimate the panel data regression. The results of WLS show that foreign ownership is positively related to corporate performance while state ownership is negatively related to corporate performance which indicates that foreign ownership enhance corporate performance while state ownership destroys corporate performance. The results also show that foreign or state ownership have linear relationship with corporate performance.

In practical perspectives, this study provides evidence to policy makers that government's proposal to increase foreign stake in Malaysian market as mentioned in NEM is supported because the increase in foreign states may improve corporate performance as a linear relationship exist. Moreover, to investors, the results of this study provide evidence that investors may make appropriate investment decisions to invest in the companies linked with foreign ownership. The theoretical implication of this study is that agency problem decreases in companies with foreign ownership while it increases in companies with state ownership. Furthermore, agency cost eliminates in companies with ownership concentration as government's NEM expects.

Future research that tries to investigate the relationship between ownership structures with corporate performance can include other variables such as firm risk and industry effects to ensure the robustness the results. Other performance measures can also be used as a proxy for company performance e.g., return on sales (ROS), return on investments (ROI), profit margin (PM), and economic value added (EVA). Then, the results can be compared with this study. This study focuses only on foreign ownership and state ownership for their influence on corporate performance. However, further research could be conducted in order to examine the other types of ownership such as domestic ownership and its linearity on corporate performance.

\section{References}

Amran, N. A. \& Ahmad, A. C. (2010). Corporate governance mechanisms and performance: Analysis of Malaysian family and non-family controlled companies. Journal of Modern Accounting and Auditing, 6 (2), 1548-6583.

Andres, C. (2008). Large shareholders and firm performance: An empirical examination of founding-family ownership. Journal of Corporate Finance, 14, 431-445.

Bekaert, G. \&Harvey, C.R. (2000). Foreign speculators and emerging equity markets. Journal of Finance 55, $565-614$

Berle, A. \& Means, G. (1932). The modern corporation and private property. New York: Harcourt, Brace \& World.

Benson, BW \& Davidson III, WN. (2009). Reexamining the managerial ownership effect on firm value. Journal of Corporate Finance, 15(5), 573-86.

Claessens, S. \& Djankov, S. (1999). Ownership concentration and corporate performance in the Czech Republic. Journal of Comparative Economics,27, 498-513. 
Claessens, S., Djankov, S., \& Lang, L. H. P. (2000). The separation of ownership and control in East Asian corporation.Journal of Financial Economics, 58, 81-112.

Coles, JL, Lemmon, ML \& Felix Meschke, J. (2012). Structural models and endogeneity in corporate finance: The link between managerial ownership and corporate performance. Journal of Financial Economics, 103 (1), 49-68.

Chhibber, P. K. \& Majumdar, S. K. (1999). Foreign ownership and profitability: property rights, control, and the performance of firms in Indian industry. Journal of Law and Economics, 42(1), 209-238.

Douma, S., George, R. \& Kabir, R. (2006). Foreign and domestic ownership, business groups, and firm performance: evidence from a large emerging market. Strategic Management Journal, 27(7), 637-657.

Estrin, S. \& Perotin, V. (1991). Does ownership always matter? International Journal of Industrial Organization, 9(1), 55-73.

Gurbuz, AO \& Aybars, A. (2010). The Impact of Foreign Ownership on Firm Performance, Evidence from an Emerging Market: Turkey. American Journal of Economics \& Business Administration, 2 (4), 350-9.

Hess, K., Gunasekarage, A., \& Hovey, M. (2010). State-dominant and non-state-dominant ownership concentration and firm performance: evidence from China. International journal of managerial finance, 6(4), 264-289.

Himmelberg, C., Hubbard, R., \& Palia, D. (1999). Understanding the determinants of managerial ownership and the link between ownership and performance. Journal of Financial Economics, 53, 353-384.

Hsioa, C. (2003). Analysis of panel data (2nded.). Cambridge: University Press.

Huang, RD \& Shiu, C-Y. (2009). Local effects of foreign ownership in an emerging financial market: evidence from qualified foreign institutional investors in Taiwan. Financial Management, 38(3), 567+.

Jensen, M. \& Meckling W. (1976). Theory of the firm: managerial behavior, agency cost, and ownership structure. Journal of Financial Economics, 3, 305-360.

Jiang, P. (2004). The relationship between ownership structure and firm performance: An empirical analysis over Heilongjiang listed companies. Nature and Science, 2(4), 87-90.

Judge, G., Hill, C., Griffiths, E., Lutkepohl, H., \& Lee, T. C. (1988). Introduction to the theory and practice of econometrics (2nd ed.). New York: John Wiley and Sons.

Khanna, T. \& Palepu, K. (2000). Is group affiliation Profitable in emerging markets? An analysis of diversified Indian business groups. Journal of Finance, 55(2), 867-891.

Konijn, SJJ, Kräussl, R, \& Lucas, A, (2011). Blockholder dispersion and firm value. Journal of Corporate Finance, 17(5), 1330-9.

Lau, Y. W. \& Tong, C. Q. (2008). Are Malaysian government-linked companies (GLCs) creating value? International Applied Economics and Management Letters, 1(1), 9-12

Le, T. V. \& Buck, T. (2009). State ownership and listed firm performance: A universally negative governance relationship? Journal of Management and Government, 10, 9098-5.

Morck, R. K., Shleifer, A., \& Vishny, R. (1988). Management ownership and market valuation: An empirical analysis. Journal of Financial Economics, 20, 293-315.

Najid, N. A. \& Abdul Rahman, R. (2011). Government ownership and performance of Malaysian government-linked companies. International Research Journal of Finance and Economics,61, 1450-2887.

Ongore, V.O. (2011). The relationship between ownership structure and firm performance: An empirical analysis of listed companies in Kenya. African Journal of Business Management, 5, (6), 2120-8.

Oxelheim, L. \& Randoy, T. (2003). The impact of foreign board membership on firm value. Journal of Banking \& Finance, 27, 23692392.

Pervan, M, Pervan, I, \& Todoric, M. (2012). Firm Ownership and Performance: Evidence for Croatian Listed Firms. World Academy of Science, Engineering and Technology, 61, 964-70.

Phung, DN \& Le, TPV. (2013). Foreign Ownership, Capital Structure and Firm Performance: Empirical Evidence from Vietnamese Listed Firms. The IUP Journal of Corporate Governance,12 (2), 40.

Qi, D., Wu, W., \& Zhang, H. (2000). Shareholding structure and corporate performance of partially privatized firms: Evidence from listed Chinese companies. Journal of Pacific Business and Finance, 8, 587-610.

Sulong, Z. \& Nor, F. M. (2010). Corporate governance mechanisms and firm valuation in Malaysian listed firms: A panel data analysis. Journal of Modern Accounting and Auditing, 1(56), 1548-6583.

Sun, Q. \& Tong, W. H. S. (2003). China share issue privatization: The extent of its success. Journal of Financial Economics, 70, 3-222.

Sun, Q., Tong, W., \& Tong, J. (2002). How does government ownership affect firm performance? Evidence from China's privatization experience. Journal of Business Finance and Accounting, 29, 1-27.

Taylor, W. (1990). Can big owners make a difference? Harvard Business Review, 68(2), 70-82.

Thomsen, S. \& Pedersen, T. (2000).Ownership structure and economic performance in the largest European companies. Strategic Management Journal, 21, 689-705.

Yu, M. (2013). State ownership and firm performance: Empirical evidence from Chinese listed companies. China Journal of Accounting Research, 6(2), 75-87.

Wang, C. (2005). Ownership and operating performance of Chinese IPOs. Journal of Banking and Finance, 29(7), 1835-1856.

Wei, Z., \& Varela, O. (2003). State equity ownership and firm performance: Evidence from China's newly privatized firms. Global Finance Journal, 14, 65-82. 